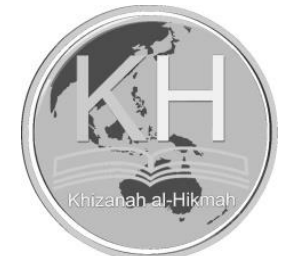

\title{
ANALYSIS AND VISUALIZATION DATA OF COVID-19 BASED ON SCOPUS
}

\author{
Tupan* \& Nur Rizzal Rosiyan*
}

*Pusat Data dan Dokumentasi Ilmiah, LIPI

Email: tupan712190@gmail.com, rizzalrosiyan@yahoo.com

(Submitted: 27-01-2021, Revised: 01-04-2021, Accepted: 03-06-2021)

DOI: $10.24252 /$ v9i1a6

\begin{abstract}
ABSTRAK: Penelitian ini menganalisis jumlah dokumentasi tentang COVID-19 berdasarkan tahun, sumber publikasi, lembaga, negara, jenis dokumen, dan lembaga pendanaan dan memetakannya berdasarkan kata kunci. Data penelitian diperoleh melalui database Scopus dengan kata kunci novel corona virus atau virus corona 2019 atau covid 2019 dan covid 19 yang selanjutnya digali. Untuk pemetaan, data Covid 19 digunakan software VOSviewer. Temuan menunjukkan bahwa ada 723 dokumen covid 19, 569 di antaranya dapat diakses secara terbuka dan 154 dapat diakses dengan berlangganan. Sebagian besar data COVID-19 yang dimuat dalam Journal of The American College of Radiology dengan kategori mata pelajaran yang dibahas adalah radiologi, kedokteran nuklir, dan pencitraan. Huazhong University of Science and Technology merupakan institusi paling produktif dalam memproduksi data covid 19. China adalah negara yang paling banyak menghasilkan data covid. Jenis dokumen data Covid 19 terbanyak adalah artikel dengan kategori mata kuliah kedokteran terbanyak. Sebagian besar sponsor pendanaan diberikan oleh National Science Foundation of China. Visualisasi data covid 19 dipetakan menjadi 5 klaster dengan kelompok terbanyak dari setiap klaster adalah klaster 1 adalah virus corona sindrom pernafasan akut parah, klaster 2 penyakit coronavirus 2019, klaster 3 demam (demam), klaster 4 epidemiologi, klaster 5 keparahan penyakit.
\end{abstract}

Kata kunci: Covid-19; bibliometrika; scopus

ABSTRACT: This study analyzes the amount of documentation about COVID-19 by year, publication source, institution, country, type of document, and funding agency and maps it based on keywords. The research data was obtained through the Scopus database with the keywords novel corona virus or corona virus 2019 or covid 2019 and covid 19, which were further explored. For mapping, the Covid 19 data, the VOSviewer software was used. The findings show that there are 723 covid 19 documents, 569 of which can be accessed openly and 154 can be accessed by subscription. Most of the COVID-19 data published in the Journal of The American College of Radiology with the subject categories discussed were radiology, nuclear medicine, and imaging. Huazhong University of Science and Technology is the most productive institution in producing covid 19 data. China is the country that produces the most covid data. The most type of Covid 19 data documents are articles with the most medicine subject category. Most of the funding sponsors were awarded by the National Science Foundation of China. The visualization of the covid 19 data was mapped into 5 clusters with the most groups from each cluster being cluster 1 being severe acute respiratory syndrome coronavirus, cluster 2 coronavirus disease 2019, cluster 3 fever (fever), cluster 4 epidemiology, cluster 5 disease severity.

Keywords: Covid-19; bibliometrics; scopus 


\section{INTRODUCTION}

The Covid-19 first appeared in Wuhan Province, Chinese, and has now become a pandemic worrying everyone. Its rapid and deadly spread has created a situation that worries governments, communities, scientists, educators, economists, and especially medical workers (Hamidah, Sriyono, \& Nur Huda, 2020). The spread can be through direct human physical contact which is transmitted through the mouth, nose, and eyes. Nurislaminingsih (2020) stated that the nature of the Covid-19 virus, which is very easily transmitted to humans, can even survive for a while on non-human objects. Efforts to break the chain of spreading the virus have been carried out in each country by issuing several regulations that the citizens should obey. The rapid spread of this virus also has an impact on the rapid distribution of data/information about Coronavirus. The digital era makes it easy for anyone to create, retrieve, edit, distribute and delete information. Regarding the corona cases, the need for public information about Covid-19 is urgent and should be provided immediately. People with certain disease backgrounds, the elderly, and pregnant women are groups of people who need special information (Nurislaminingsih, 2020).

Coronavirus is an RNA virus with a particle size of $120-160 \mathrm{~nm}$. This virus mainly infects animals, including bats and camels. Previously, 6 types of coronavirus could infect humans, namely alphacoronavirus 229E, alphacoronavirus NL63, betacoronavirus OC43, betacoronavirus HKU1, Severe Acute Respiratory Illness Coronavirus (SARS-CoV), and the Middle East Respiratory Syndrome Coronavirus (MERS-CoV). The coronavirus that is the etiology of Covid-19 belongs to the betacoronavirus genus. The results of phylogenetic analysis show that this virus belongs to the same subgenus as the coronavirus that caused the Severe Acute Respiratory Illness (SARS) outbreak in 2002-2004 ago, namely Sarbecovirus. International Committee on Taxonomy of Viruses phylogenetic analysis proposed the name SARS-CoV-2.1. The SARS-CoV-2 sequence is similar to the coronavirus isolated in bats, leading to the hypothesis that SARS-CoV-2 originated in bats and then mutated and infects humans. Mammals and birds are thought to be intermediate reservoirs. Currently, the spread of SARS-CoV-2 from human to human is the main source of transmission so that the spread becomes more aggressive. Transmission of SARS-CoV-2 from symptomatic patients occurs through droplets released when coughing or sneezing (Susilo et.al, 2020).

Since March 2020, the pandemic has attracted the attention of academia, sparking a new wave of research on Covid-19. However, most of the recent studies are mostly related to health issues and not other aspects such as less explored areas including life and social sciences. In addition, in research publications, there are also gaps among topics that are mostly studied and some are rare. Chahrour et.al (2020) and Lou et.al (2020), for example, analyzed the document using the Pubmed database. For this reason, a comprehensive study is needed that uses the Scopus database which includes the amount of Covid-19 data, publication sources, institutions, countries, types of documents, and funding institutions as well as visualizing research maps on Covid based on keywords. This study aims to determine the number of covid data publications by year, publication source, institution, country, type of document, and funding institution as well as visualization of Covid-19 data based on keywords from the Scopus database.

\section{PREVIOUS FINDINGS}

A study was carried out by Chahrour et.al (2020 has analyzed research activities on Covid-19. The researchers used the Pubmed database to find out publications related to the coronavirus based on the keywords 'novel coronavirus 2019', 'coronavirus 2019', 'covid 2019', and 'Covid-19'. The results of their research showed that 564 publications met the criteria for analysis. Publications come from 39 different countries, which is $24 \%$ of all countries affected by Covid-19. China produces the most publications with 377 publications (67\%).

Other research is conducted by Lou et.al (2020). This study reviews and analyzes Coronavirus 2019 by the bibliometric method. The study used the PubMed database with the keywords 'Covid-19'. Search results are identified and analyzed by title, appropriate author, 
language, time of publication, type of publication, research focus. The results showed that there were 183 publications on Covid-19 published from January 14, 2020, to February 29, 2020. The authors of the publication come from 20 different countries. The author's agencies were 78 (42.6\%) from hospitals, 64 (35\%) from universities, and 39 (21.3\%) from research institutes. All publications are published in 80 different journals. The Medical Virology Journal published the most Covid-19 publications, namely 25 publications. There were $60(32.8 \%)$ articles, $29(15.8 \%)$ reviews, and $20(10.9 \%)$ brief communications. Based on the keywords showed that $68(37.2 \%)$ epidemiological, 49 (26.8\%) virological, and 26 (14.2\%) clinical features.

Vermaa and Gustafsson (2020) investigate the emerging Covid-19 research trends in the business and management fields by also using a bibliometric analysis approach. This study presents the findings of a bibliometric study of the Covid-19 literature in the business and management fields to identify current research areas and propose future solutions. An analysis of the published literature identified four main research themes and 18 sub-themes. The findings and propositions of this study have indicated that Covid-19 will be a catalyst for several long-term and short-term policy changes and requires theoretical and empirical attention from researchers. The propositions offered will act as a roadmap to potential research opportunities.

By using a different database, Yu et.al (2020) analyzed Covid-19 publications obtained from the Web of Science database. The results showed that as many as 15,805 publications on the topic have been identified from the database. Between 2019 and 2020, there were 10,601 (67.1\%) publications were published in the form of articles, 1,189 (7.5\%) review articles, 2,296 (14.5\%) editorials, and 1,719 other publications including letters, case reports, etc. Almost all 14,609 publications (92.4\%) were written in English, followed by the Chinese language with 623 publications and 11,575 (73.2\%) publications were accessible. Neto et.al (2020) also used the Web of Science database. Their study showed that the most international publications on Covid19 are in the form of articles, published in 36 journals and China is the country that publishes the most, with 25 publications. Other similar researches are also conducted by De Felice \& Polimeni (2020), Mao, Guo, Fu \& Xiang (2020), Zyoud (2016), Joshua \& Sivaprakasam (2020).

\section{RESEARCH METHODOLOGY}

This study uses the literature search method. The research method includes research data sources, search strategies, and data analysis. The data was obtained from the Scopus database which is the largest data center in the world that includes tens of millions of scientific literature published decades ago until today. Scopus has the main function of creating an index of scientific literature to provide accurate information about the metadata of each scientific article, including publication data, abstracts, references, and others (Fauzy, 2016)

The data was collected by conducting a literature search related to Covid-19 indexed by Scopus. The data began to be collected from June 29, 2020, using the keywords: Title (Novel and coronavirus 2019) or Title (Coronavirus 2019) or Title (covid 2019) and Title (Covid-19)). The search using this strategy finally found 723 data on Covid-19 publications. Furthermore, bibliographic data and keywords from 723 articles were extracted in CSV format and keyword maps were visualized using VosViewer software.

\section{RESULTS AND FINDINGS}

\section{The Number of Publications Per Year}

From the search results through the Scopus database in 2020, it was found 723 documents consisting of 569 which were openly accessible while the remaining 154 documents could be accessed by subscription or paid.

The most and reputable journals

From a total of 158 journal titles, Table 1 below shows the rankings of the twenty-eight major journals $(17.72 \%$,) that contain the greatest number of Covid-19 data publications. Of the twenty- 
eight ranked journals that contain publications about Covid-19, including journals with the first quartile rank (Q1) and have a relatively high CiteScore. The majority of publications come from health journals on the subject of cardiology and cardiovascular medicine.

Table 1. The reputable journals that contain literature on Covid-19 data publications

\begin{tabular}{|c|c|c|c|}
\hline Journal Names & $\begin{array}{l}\text { Number of } \\
\text { Publications }\end{array}$ & $\begin{array}{l}\text { CiteScore } \\
2019 \\
\end{array}$ & Subjects \\
\hline $\begin{array}{llll}\text { Journal of the American College of } \\
\text { Radiology (Q1) }\end{array}$ & 29 & 3,4 & $\begin{array}{l}\text { Radiology, Nuclear medicine and } \\
\text { imaging }\end{array}$ \\
\hline World Neurosurgery (Q2) & 16 & 2,4 & $\begin{array}{l}\text { Medicine } \\
\text { neurology }\end{array}$ \\
\hline JAMA Cardiology (Q1) & 11 & 16,2 & $\begin{array}{l}\text { Cardiology and cardiovascular } \\
\text { medicine }\end{array}$ \\
\hline Journal Of Infection (Q1) & 11 & 8,0 & Infectious diseases, Microbiology \\
\hline Journal Of Medical Virology (Q2) & 11 & 4,0 & $\begin{array}{l}\text { Infectious disease, Immunology and } \\
\text { microbiology }\end{array}$ \\
\hline $\begin{array}{l}\text { Clinical Infectious Diseases an Official } \\
\text { Publication Of The Infectious Diseases } \\
\text { Society Of America (Q1) }\end{array}$ & 10 & 12,5 & Infectious diseases, Microbiology \\
\hline European Radiology (Q1) & 10 & 6,9 & $\begin{array}{l}\text { Radiology, Nuclear medicine and } \\
\text { imaging }\end{array}$ \\
\hline $\begin{array}{l}\text { Infection Control and } \quad \text { Hospital } \\
\text { Epidemiology (Q1) }\end{array}$ & 9 & 4,5 & $\begin{array}{l}\text { Infectious diseases, Microbiology, } \\
\text { Epidemiology }\end{array}$ \\
\hline International Journal of Surgery (Q1) & 9 & 6,0 & Surgery \\
\hline Annals Of Internal Medicine (Q1) & 8 & 14.6 & Internal medicine \\
\hline $\begin{array}{l}\text { Clinical Chemistry and Laboratory } \\
\text { Medicine (Q1) }\end{array}$ & 8 & 6,4 & $\begin{array}{l}\text { Biochemistry, Genetics } \\
\text { Molecular Biology }\end{array}$ \\
\hline JAMA Network Open (Q1) & 8 & 1,7 & $\begin{array}{l}\text { Radiology, Nuclear medicine and } \\
\text { imaging }\end{array}$ \\
\hline Chinese Traditional and Herbal Drugs (Q3) & 7 & 0.3 & $\begin{array}{l}\text { Pharmacology, Toxicology and } \\
\text { Pharmaceutics }\end{array}$ \\
\hline JAMA Pediatrics (Q1) & 7 & 18,2 & $\begin{array}{l}\text { Pediatrics, Perinatology and Child } \\
\text { Health }\end{array}$ \\
\hline $\begin{array}{l}\text { Journal of the American Academy of } \\
\text { Dermatology (Q1) }\end{array}$ & 7 & 6,7 & Dermatology \\
\hline Korean Journal of Radiology (Q1) & 7 & 4,5 & $\begin{array}{l}\text { Radiology, Nuclear medicine and } \\
\text { imaging }\end{array}$ \\
\hline $\begin{array}{l}\text { JAMA Journal of The American Medical } \\
\text { Association (Q1) }\end{array}$ & 6 & 26,3 & General medicine \\
\hline Obstetrics And Gynecology (Q1) & 6 & 6,7 & Obstetrics and Gynecology \\
\hline $\begin{array}{l}\text { European Review for Medical and } \\
\text { Pharmacological Sciences (Q2) }\end{array}$ & 5 & 3,5 & Pharmacology (medical) \\
\hline Eurosurveillance (Q1) & 5 & 11,1 & $\begin{array}{l}\text { Immunology and Microbiology, } \\
\text { Virology, epidemiology }\end{array}$ \\
\hline $\begin{array}{l}\text { International Journal of Antimicrobial } \\
\text { Agents (Q1) }\end{array}$ & 5 & 6,7 & $\begin{array}{l}\text { Infectious diseases, Pharmacology, } \\
\text { Microbiology }\end{array}$ \\
\hline $\begin{array}{l}\text { International Journal of Environmental } \\
\text { Research and Public Health (Q2) }\end{array}$ & 5 & 3,0 & $\begin{array}{l}\text { Public Health, Environmental and } \\
\text { Occupational Health }\end{array}$ \\
\hline $\begin{array}{l}\text { International Journal of Infectious Diseases } \\
\text { (Q1) }\end{array}$ & 5 & 5,3 & Infectious diseases, Microbiology \\
\hline $\begin{array}{l}\text { Journal Of Cardiothoracic and Vascular } \\
\text { Anesthesia (Q2) }\end{array}$ & 5 & 2,9 & $\begin{array}{l}\text { Anesthesiology and Pain Medicine, } \\
\text { Cardiology and Cardiovascular } \\
\text { Medicine }\end{array}$ \\
\hline
\end{tabular}




\begin{tabular}{llll} 
Medical Hypotheses (Q3) & 5 & 2,2 & General medicine \\
Medical Journal of Australia (Q2) & 5 & 3,6 & General medicine \\
Medical Science Monitor (Q2) & 5 & 2,7 & General medicine \\
\hline
\end{tabular}

The top ten most productive institutions

Table 2. The top ten most productive institutions

\begin{tabular}{lc}
\hline \multicolumn{1}{c}{ Institutions } & $\begin{array}{c}\text { Number of } \\
\text { Publications }\end{array}$ \\
\hline Huazhong University of Science and Technology & 22 \\
Università degli Studi di Verona & 21 \\
Tongji Medical College & 20 \\
Cincinnati Children's Hospital Medical Center & 17 \\
Zhongnan Hospital of Wuhan University & 16 \\
Harvard Medical School & 14 \\
The University of Hong Kong & 13 \\
Icahn School of Medicine at Mount Sinai & 13 \\
Peking Union Medical College Hospital & 11 \\
Shahid Beheshti University of Medical Sciences & 11 \\
\hline
\end{tabular}

The top ten most productive countries

Table 3. The top ten most productive countries

\begin{tabular}{lc}
\hline \multicolumn{1}{c}{ Countries } & $\begin{array}{c}\text { Number of } \\
\text { Publications }\end{array}$ \\
\hline China & 244 \\
United States & 201 \\
Italy & 83 \\
United Kingdom & 42 \\
Iran & 32 \\
France & 24 \\
Singapore & 23 \\
India & 22 \\
Canada & 20 \\
Australia & 19 \\
\hline
\end{tabular}

The number of publications by the document types

Table 4. The number of publications by the document types

\begin{tabular}{lc}
\hline Document types & $\begin{array}{c}\text { Number of } \\
\text { Publications }\end{array}$ \\
\hline Article & 386
\end{tabular}




\begin{tabular}{lc} 
Letter & 131 \\
Review & 106 \\
Note & 47 \\
Editorial & 40 \\
Short Survey & 9 \\
Erratum & 3 \\
Conference Paper & 1 \\
$\quad$ Total & 723 \\
\hline
\end{tabular}

The number of publications by subjects

Table 5. The number of publications by subjects

\begin{tabular}{|c|c|}
\hline Subjects & $\begin{array}{c}\text { Number of } \\
\text { Publications }\end{array}$ \\
\hline Medicine & 659 \\
\hline Biochemistry, Genetics and Molecular Biology & 68 \\
\hline Immunology and Microbiology & 53 \\
\hline Pharmacology, Toxicology and Pharmaceutics & 32 \\
\hline Environmental Science & 15 \\
\hline Neuroscience & 14 \\
\hline Nursing & 13 \\
\hline Health Professions & 9 \\
\hline Social Sciences & 9 \\
\hline Computer Science & 8 \\
\hline Dentistry & 8 \\
\hline Engineering & 7 \\
\hline Agricultural and Biological Sciences & 6 \\
\hline Mathematics & 4 \\
\hline Veterinary & 3 \\
\hline Business, Management and Accounting & 2 \\
\hline Multidisciplinary & 2 \\
\hline Arts and Humanities & 1 \\
\hline Chemistry & 1 \\
\hline Economics, Econometrics and Finance & 1 \\
\hline Energy & 1 \\
\hline Psychology & 1 \\
\hline Undefined & 1 \\
\hline Total & 723 \\
\hline
\end{tabular}


The number of publications by funding sponsors

Table 6. The number of publications by funding sponsors

\begin{tabular}{|c|c|}
\hline Funding Sponsor Agencies & $\begin{array}{c}\text { Number of } \\
\text { Publications }\end{array}$ \\
\hline National Natural Science Foundation of China & 25 \\
\hline National Basic Research Program of China (973 Program) & 5 \\
\hline Conselho Nacional de Desenvolvimento CientÃfico e TecnolÃgico & 4 \\
\hline Fundamental Research Funds for the Central Universities & 4 \\
\hline Ministry of Education of the People's Republic of China & 4 \\
\hline China Postdoctoral Science Foundation & 3 \\
\hline CoordenaÃßÃ£o de AperfeiÃßoamento de Pessoal de NÃvel Superior & 3 \\
\hline Medtronic & 3 \\
\hline National Institutes of Health & 3 \\
\hline National Major Science and Technology Projects of China & 3 \\
\hline Natural Science Foundation of Guangdong Province & 3 \\
\hline AbbVie & 2 \\
\hline Amgen & 2 \\
\hline Bayer & 2 \\
\hline Centers for Disease Control and Prevention & 2 \\
\hline FundaÃß̊̃̃£o de Amparo Ã Pesquisa do Estado de Minas Gerais & 2 \\
\hline Harbin Engineering University & 2 \\
\hline Japan Society for the Promotion of Science & 2 \\
\hline Ministry of Education, Culture, Sports, Science and Technology & 2 \\
\hline National Cancer Institute & 2 \\
\hline National Health and Medical Research Council & 2 \\
\hline National Institute for Health Research & 2 \\
\hline National Institute of Allergy and Infectious Diseases & 2 \\
\hline National Medical Research Council & 2 \\
\hline National Research Foundation of Korea & 2 \\
\hline National Science Foundation & 2 \\
\hline Pfizer & 2 \\
\hline Sichuan University & 2 \\
\hline State Key Laboratory for Diagnosis and Treatment of Infectious Diseases & 2 \\
\hline Universitat de ValÃ̈ncia & 2 \\
\hline
\end{tabular}

\section{Visualization of Covid-19 data based on keywords}

It describes the keyword visualization results generated using the VosViewer software (Figure 1). This keyword visualization was carried out as an initial stage to find out the general description and topics of the most widely used Covid-19 data publications (Nadzar, Bakri, and Ibrahim 2017). The most used keywords are marked with a larger circle size. The connecting lines between keywords indicate how often they are used together in a publication. The thicker and more lines the more often these keywords appear in the publication. 


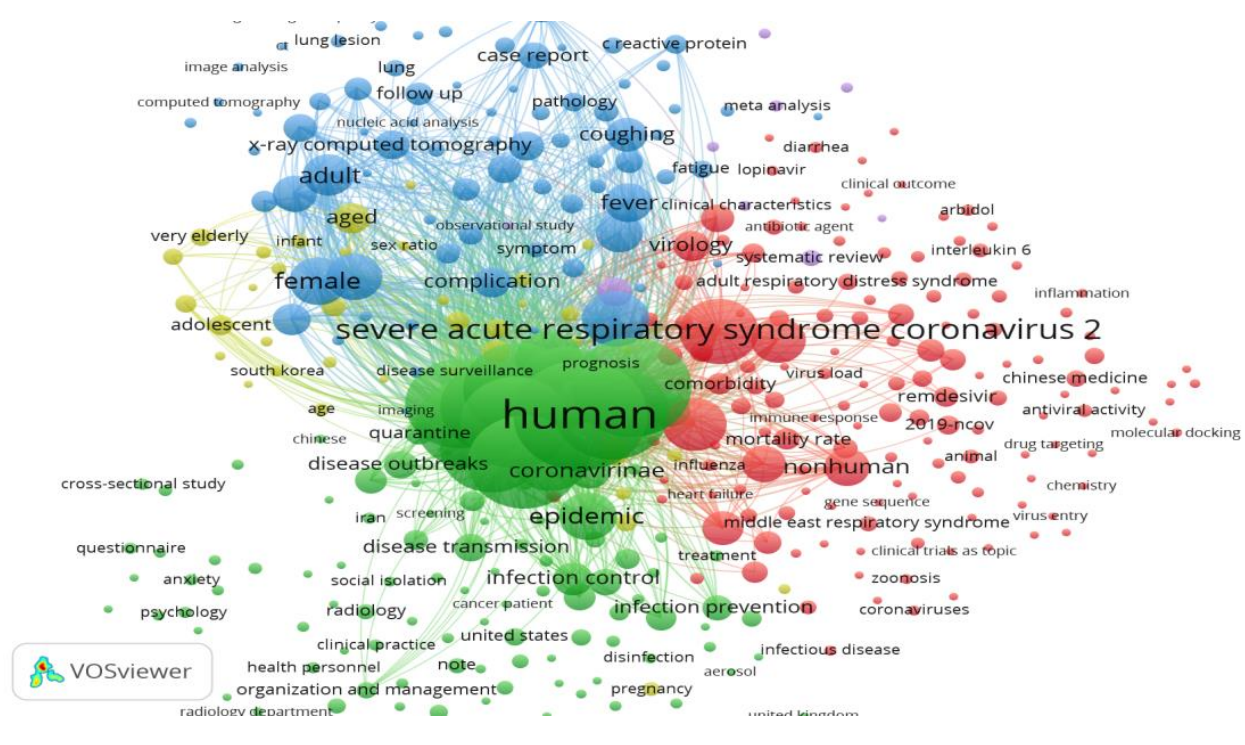

Figure 1. Mapping scientific publications about Covid-19 based on keywords

As seen Figure 1 has highlighted five major keyword clusters often used in research publications about Covid-19 as follows.

The $1^{\text {st }}$ Cluster

The red circles consist of; novel coronavirus 2019, 2019-ncov, acute kidney failure, alpha interferon, angiostensin converting, angiostensin reseptor antagonist, antibiotic agent, antiinflammatory activity, antiviral activity, antiviral agents, antiviral teraphy, antivirus agent, artificial ventilation, azithromycin, cardiovascular disease, cardiovascukar diseases, chemical composition, chemistry, chinese drug, chinese medicine, chloroquine, clinical feature, clinical outcome, communicable disease, coronavirus diseases 2019 (covid-19), coronaviruses, corticosteroid, covid-19 vaccine, critical illness, critically ill patient, cytokine, cytokine strom, diabetel mellitus, diagnostic prosedure, disease managament, drug effect, drug eficacy, drug mechanism, drug repositioning, drug safety, drug targeting, extracorporeal oxygenation, gene sequence, genetics, global health, glucocorticoid, heart failure, heart injury, herbaceous agent, hydroxychloroquine, hypoxemia, immune response, immunoglobulin, immunology, immunosupprresive treatment, incubation time, infection rate, infectiuous diseases, infectious disesases, inflamation, influenza, intensive care, intensive care unite, interferon, isolation, lung injury, malaria, malignan neoplasm, medical research, medicine, chinese traditional, metabolism, methylprednisolone, midle east respiratory sindrome, molecular docking, mortality rate, network pharmacology, noninvasive ventilation, outbreak, oxygen teraphy, pathogenesis, pathophyisiology, physiology, prediction, prevalence, protein expression, quercetin, respiratory failure, raspiratory tract infection, sars coronavirus, sars virus, sars-cov, sars-cov-2, sarsrelated coronavirus, severe acute rspiratory, traditional chinese medicine, transmission, tumor necrosis factor, viral vaccines, virology, virus entry, virus genome, virus load, virus morphology, virus replication, virus transmission, virus vaccine, virus virulence, wordl heath organization, wuhan dan zoonosis.

\section{The $2^{\text {nd }}$ Cluster}

The green circles consist of: algorithm, anxiety, attitude to heath, betacoronavirus, cancer patient, cerebrovascular accident, chinese, clinical decision making, clinical practice, clinician, comunicable disease control, coronavirinae, coronavirus, coronavirus disease 2019, coronavirus infections, Covid19, cross infection, cros sebtional studies, cross sebtional study, depresion, devices, diagnosis, disease control, disease outbreaks, disease transmission, disease transmission, infection, disinfection, 
education, elective surgery, emergency, emergency care, emergency health service, epidemic, epidemics, hand washing, health care, health care delivery, health care personil, health care planning, heath care system, health personal, health survey, high risk population, hospital, hospital infection, hospital management, immunocompromissed patient, infection control, infection prevention, infection risk, infection sensitivity, infection disease transmission, medical education, medical ethics, medical staff, mental health, mental stress, morbidity, neorosurgery, novel coronavirus, ocupational safety, organization and management, pandemic, pandemics, patient care, patient safety, personal protective equitment, pneumonia, prevention and control, protective equitment, public health, public heath service, quarantine, radiologist, radiology, radiology departement, respiratory disease, respiratory tract disease, risk assesment, screening, social distance, social isolation, stress physological, stroke, surgery, surveys and questionari, symtomatology, teleheath, telemedicine, viral contamination, dan virus pneumonia.

The $3^{\text {rd }}$ Cluster

The blue circles consist of; alanine aminotransferase, asparate aminotransferase, body temperature, breathing rate, reactive protein, case report, ches tightness, clinical laboratory techniques, comparative study, complication, computed tromography, computer assisted tromography, contac examination, controlled study, diagnostic imaging, defferential diaagnotis, disease course, disease exacerbation, dispnea, early diagnosis, fatigue, gastrointestinal disease, headhace, hemoptysis, hospital admission, hospital discharge, hipertension, image analisis, infection, infection and purification, laboratory technique, laboratory test, lactate dehydrogenase, leucocyte count, leucopenia, lung disease, lung lesion, lung nodule, limphocyte count, limphocytopenia, major clical study, medical history, midle aged, nucleic acid, nucleic acid analysis, oxygen saturation, pathology, patient dischage, patient isolation, phylogeny, pleura efussion, pneumonia, radiography thoracic, real time reserve transciption polymerase chain reaction, restrospective study, reverse transcriptase polymerase chain reaction, sensitivity and specificity, sore throat, sputum analysis, symthon, thorax, thorax radiography, thoat culture, thomography, tomography x ray com, virus detection, $x$-ray computed tomography.

The $4^{\text {th }}$ Cluster

The yellow circles consist of; adolescent, age distribution, age factor, aged 80 and over, asymptomatic infection, case fatality rate, child, preschool, disease surveillance, epidemiological data, epidemiology, geographic distribution, hospital patient, hospitalization, infant, newborn, laboratory diagnosis, mortality, pathogenicity, pediatrics, polymerase chain reaction, pregnancy, pregnant women, preschool child, real-time polymerase chain reaction, respiratory distress, risk factor, the severity of illness index, treatment outcome, very elderly, young adult.

The $5^{\text {th }}$ Cluster

The purple circles consist of; blood, clinical characteristic, disease severity, length of stay, metaanalysis, observational study, platelet count, prognosis, randomized controlled trial and systematic review.

Based on the visualization of the five clusters above, it shows that the most cluster appeared in the first cluster, namely severe acute respiratory syndrome coronavirus, followed by the second cluster coronavirus disease 2019, the third cluster fever, the fourth cluster epidemiology, and the fifth cluster disease severity. The study is in line with the results of a study conducted by Lou et.al (2020) which reviewed and analyzed the 2019 Coronavirus with the bibliometric method. The results of the analysis showed that based on keywords 68 (37.2\%) epidemiology, 49 (26.8\%) virology, and $26(14.2 \%)$ clinical features.

\section{CONCLUSION}

Based on the findings above, it can be concluded that the Covid-19 data indexed in the Scopus database was only carried out in 2020. The data publication of Covid-19 was 723 documents of which 569 were openly accessible and the remaining 154 documents could be accessed by 
subscription. The journal that publishes data on COVID-19 is the Journal of the American College of Radiology with the subject categories discussed are radiology, nuclear medicine, and imaging. Huazhong University of Science and Technology is the institution that publishes the most data on Covid-19 that have 22 publications. China is the largest country with having publications as many as 244 documents. In terms of the type of data publication documents, the most are in the form of articles which are 386 documents with the most subject category was medicine with 659 publications. The most funding sponsors were provided by the National Science Foundation of China, followed by the National Basic Research Program of China. The visualization using VosViewer Covid-19 data mapped into five clusters as described before.

\section{REFERENCES}

Chahrour, M., Assi, S., Bejjani, M., Nasralla, A. A., Salhab, H., Fares, M., \& Khachfe, H. H. (2020). A Bibliometric Analysis of COVID-19 Research Activity: A Call for Increased Output. Cureus, 12(3), 1-8. https://www.ncbi.nlm.nih.gov/pmc/articles/PMC7174863/ Diakses 24 Juli 2020

De Felice, F., \& Polimeni, A. (2020). Coronavirus disease (COVID-19): A machine learning bibliometric analysis. In Vivo, 34, 1613-1617. https://doi.org/10.21873/invivo.11951. Diakses 25 Juli 2020

Fauzy, A. (2016). Pemetaan Unggulan Riset. Yoyakarta: Universitas Islam Indonesia

Hamidah, I., Sriyono., Nur Huda, M. (2020). A Bibliometric Analysis of Covid-19 Research using VOSviewer. Indonesian Journal of Science \& Technology, 5(2), 34-41.

http://ejournal.upi.edu/index.php/ijost/. Diakses 24 Juli 2020

Joshua, V. and Sivaprakasam, S. (2020). Coronavirus: Bibliometric analysis of scientific publications from 1968 to 2020. Med J Islam Repub Iran, 34 (64), 1-8. https://doi.org/10.34171/mjiri.34.64. Diakses 25 Juli 2020

Lou, J., Tian, S.-J., Niu, S.-M., Kang, X.-Q., Lian, H.-X., Zhang, L.-X., Zhang, J.-J. (2020). Coronavirus disease 2019: a bibliometric analysis and review. European Review for Medical and Pharmacological Sciences, 24 (6), 3411-3421

Mao, X., Guo, L., Fu, P., Xiang, C. (2020). The Status and Trends of Coronavirus research A global bibliometric and visualized analysis. Medicine, 99 (22), 1-8

Neto, JF., Moura Filho, E. P., Santos, E. ME., Carvalho, M. N., Nery R. P., Pinto, A. SB. (2020). Bibliometric Study of International Scientific Production on the Novel Coronavirus COVID-19. IntJ Clin Med Cases, 3(6), 15

Nurislaminingsih, R. (2020). Layanan Pengetahuan tentang Covid-19 di Lembaga Informasi. Tik Ilmeu : Jurnal Ilmu Perpustakaan dan Informasi, 4(1), 19-37

Parwanto, MLE. (2020). Virus Corona (2019-nCoV) penyebab COVID-19. Jurnal Biomedika dan Kesehatan, 3(1), 1-2

Susilo, A., Rumende, C. M., Pitoyo, C. W., Santoso, W. D., Yulianti, M., Herikurniawan., Sinto, R., Singh, G., Nainggolan, L., Nelwan, E. J., Chen, L. K., Widhani., Alvina., Wijaya, E., Wicaksana, B., Maksum, M., Annisa, F., Jasirwan, C. OM., Yunihastuti, E. (2020). Coronavirus Disease 2019: Tinjauan Literatur Terkini. Jurnal Penyakit Dalam Indonesia, 7(1), 45-67

Supriatna, E. (2020). Wabah Corona Virus Disease Covid-19 Dalam Pandangan Islam. SALAM; Jurnal Sosial \& Budaya Syar-I, 7(6), 555-564

Syafrida., \& Hartati, R. (2020). Bersama Melawan Virus Covid-19 di Indonesia. SALAM; Jurnal Sosial \& Budaya Syar-I, 7(6), 495-508

Vermaa,Surabhi and Gustafssonb,Anders. (2020). Investigating the emerging COVID-19 research trends in the field of business and management: A bibliometric analysis approach. Journal of Business Research, 118, 253-261

Yu Yuetian; Li Yujie; Zhang, Zhongheng; Gu, Zichun; Zhong, Han; Zha, Qiongfang; Yang, Luyu; Zhu Cheng; Chen, Erzhen. (2020). A bibliometric analysis using VOSviewer of publications on COVID-19. Ann Transl Med, 8(13), 816, doi: 10.21037/atm-20-4235 
Zyoud, S. H. (2016). Global research trends of Middle East respiratory syndrome coronavirus: a bibliometric analysis. BMC Infectious Diseases,16(255),1-7. 